\title{
重田琞 明
}

\section{（松下電器産嗪株式会社照明研究所）}

1.はとぬに

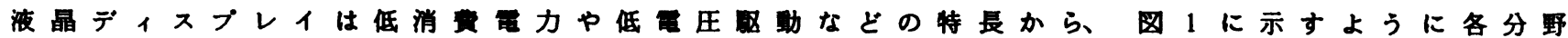
に応用されている'。液晶表示素子はCRT,PDP, E L , L B d どの発光型素子と建って非発光型 素子のため、自然光や人工光など何らかの照明を必要 とする。れる実現するものとしてバックライト（背 面照明)がある。こでは液晶ディスプレイ用ハッッ クライトについて、直視型の液晶ディスプレイ(ビュー ファインダ，小型テレビ，パソコン，ワープロなど)用ハ ックライトの要求性能，方式，槽成要素を概説し、おわ せて大画面化の一方法として普及しはしめた投写型の 液晶ディスプレイ（液晶プロジェク夕）用バックライ 卜（光源システム）の概要を述へる。

2. バックライ上に要求される性能

液晶ディスプレイ用バックライトに要求される性能 は、視党的な条件から（1）高耀度（モノ)名表: $500 \sim 1,50$

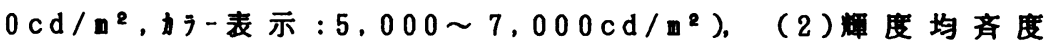

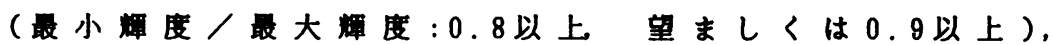

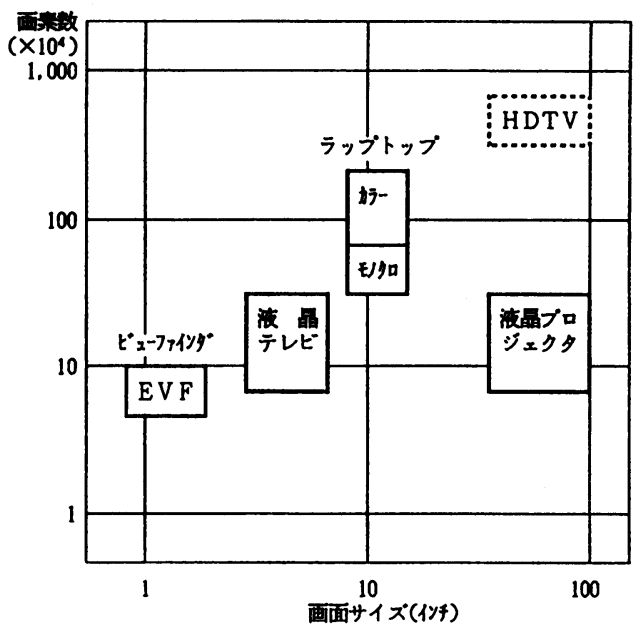

因1液晶 $匚 * 1 ス 7 ・ v 1 の$ 利用分野い (3)色再現性(色温度: $6.000 \sim 10,000 \mathrm{~K}, \mathrm{NTSC}$ 方式に变拋

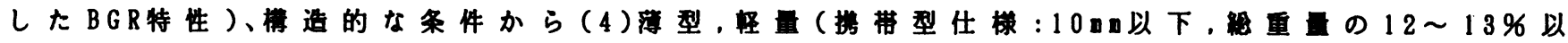

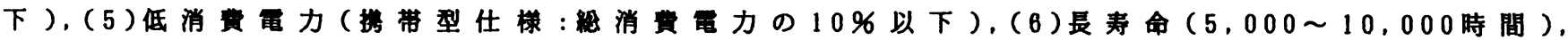

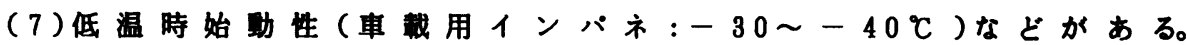

3. ハックラ1上の左式 2

ハックライトの方式には表 1 に示す種類と特

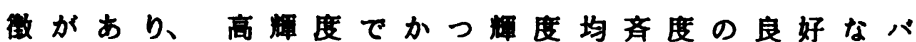
ックライトを実現するために、それそれの要求 にもとついた方式が使い分けられている。

[面状光源方式]平板型冷陰栖鉴光ランブの課

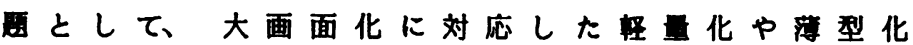
汃分散型ELでは高輝度化長寿命化眨 回路の低音化などがある。

[反射板(直下, スクリーン)方式] 橝题として 型型化、度の均一化などかる。

[迺光体(エッジライト)方式]眯通として高 碘度化，軽量化などがあ。

\section{4.バックライトの主要㮛成要表}

バックライトは、光源（监光ランプ,LED,E 几, 白熱 [八口ゲン]電球など)之光源からの照 射光の光目，分布，方向などを制御する光学 部材（光反射部材，光拡散部材，光均一部材， 䓕光体部材など）加槽成される。ハック

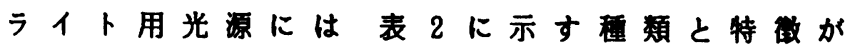
あり ${ }^{3} 、$ 潭度, 発光効事, 寿命などの特長か ら监光ランプが多用される。 Back-1ighting for LCDS,

表 1 バックライト方式の顬と特改”

\begin{tabular}{|c|c|c|}
\hline 方式(糧頪) & 特 & 使 用 光 源 \\
\hline 面状光源 & 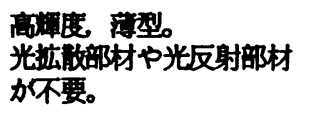 & 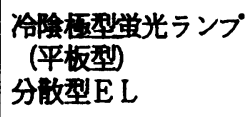 \\
\hline $\begin{array}{c}\text { 反射板 } \\
\text { (直 下) } \\
\text { (スクリーン) }\end{array}$ & 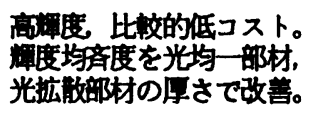 & 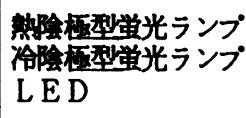 \\
\hline 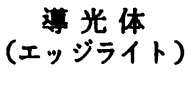 & 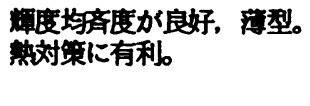 & 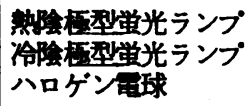 \\
\hline 外 光 & 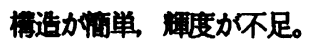 & 自然光 一般照明光 \\
\hline
\end{tabular}
表 2 バックライト用光源の種類と特繳”

\begin{tabular}{|c|c|c|c|c|c|c|}
\hline 光源の和䫐 & \multirow{2}{*}{ 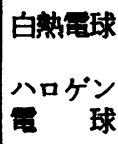 } & \multirow{2}{*}{ LED } & \multirow{2}{*}{ E L } & \multicolumn{3}{|c|}{ 监光ランブ } \\
\hline $\begin{array}{c}\text { バックライト } \\
\text { 要 件 }\end{array}$ & & & & 整型 & $\begin{array}{l}\text { 冾险唒 } \\
\text { 型 }\end{array}$ & $\begin{array}{c}\text { (平板) } \\
\text { 型 }\end{array}$ \\
\hline 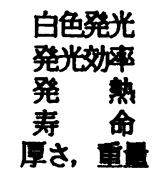 & $\begin{array}{l}x \\
x \\
x \\
\Delta \\
0\end{array}$ & $\begin{array}{l}x \\
x \\
0 \\
0 \\
0 \\
0\end{array}$ & $\begin{array}{c}\Delta \\
\times \\
0 \\
\times \\
0(0)\end{array}$ & $\begin{array}{l}\stackrel{0}{0} \\
\bigcirc \\
\triangle \\
\triangle \\
\triangle\end{array}$ & $\begin{array}{l}0 \\
\triangle \\
0 \\
0 \\
0\end{array}$ & $\begin{array}{l}0 \\
\Delta \\
\Delta \\
0 \\
x\end{array}$ \\
\hline
\end{tabular}




\section{5. 各種デ、スプレイ用ハックライトの技行助向}

[ビューフォインダ用] 小型化，低消費電力化，色再現性の改善などが的面て、特に、短時 間での躁り返し使用に耐える信頼性が要求される。

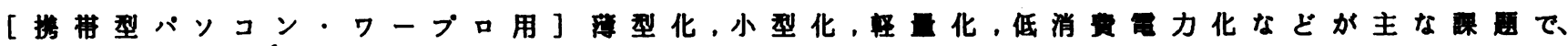

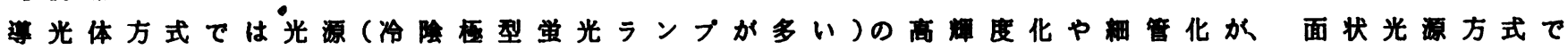
は光源（分票型 E L が多い）の長寿命化や助回路の低音化か要求される。

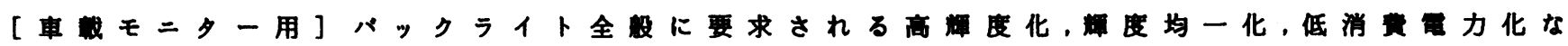

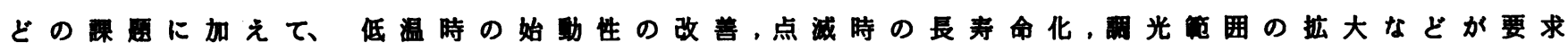
むれる。

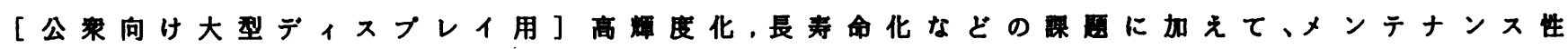
の改善やコントラストの向上などか要求される。

6. 液晶プロジェク夕用光源システム

1〜3インチの小型の液晶表示素子にバックライト(光源システム)の光を照射し、をの画 像を投写レンズでスリーンに拡大投写するものが液晶ブロジェク夕である。基本方式と して、フント方式(前面投写方式)とリア方式(背面投写方式)がる。

波晶ブロジェク夕用光源システムには（1）N T S C 方式のB G Rに対応する発光スへク トルを持つこと（2）形状や発光部分がさく、高解度て平行光に近いこと（3)発光効事か

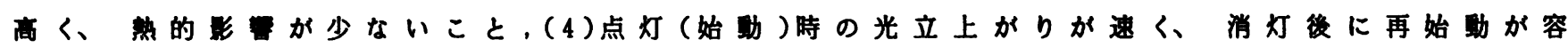

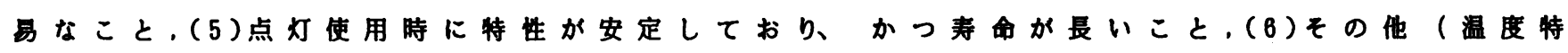

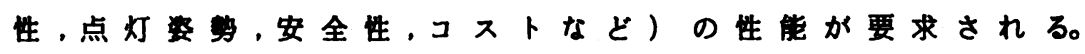

光源システムは光源(ハロゲン電球，キセノンランプロメタルハライトランプなど)と 2 炊

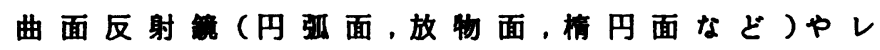

ンズから棏成される。

このような粠成において、上記の要求性能 をすへて渵足する光源はないがその中での 発光スべトル，点光源，(発光効高などの 特性から、現状では150〜250Wのメタル八ラ イドンプが多用されている。表 3 に液晶ブ 口ジェク夕用光源の㮌類と特改を示すい。

光源システムの高解度化や長寿命化ある いは色再現性や色ムラの改善対策として、器 光管内に対向する電栖の片侧を長くして、ア

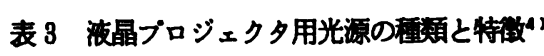

\begin{tabular}{|c|c|c|c|}
\hline & ハロゲン球 & $\begin{array}{l}\text { キセノンラン } \\
\text { プ }\end{array}$ & $\begin{array}{l}\text { メタルハライ } \\
\text { ドランブ }\end{array}$ \\
\hline 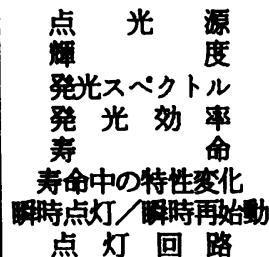 & $\begin{array}{c}x \\
\times \\
\times \\
\times \\
\triangle \\
0 \\
O \\
O \text { (不要) }\end{array}$ & $\begin{array}{l}0 \\
0 \\
0 \\
\times \\
\Delta \\
0 \\
0 \\
x\end{array}$ & 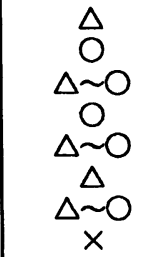 \\
\hline
\end{tabular}

O:良 $\triangle$ : 中良 $x:$ 不十分

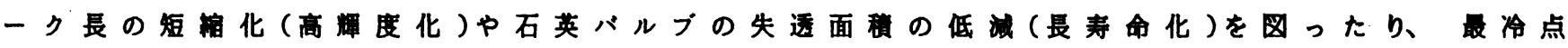
温度の上昇, バルブのフロスト加工（色再現性，色ムラの改善)などが試るられている。

7. お力りに

以上、直视の型晶ディスプレイ用ハックライトと投写型の液晶ディスプレイ用光源シ ステムの技術助向を述へた。液晶ディスプレイは各分野て利用されることが予想されるこ とから、バックライトや光源システムの技術開発は液晶表示素子の開発と相まって進めら れる。今後液晶表示素子の光透通特性か改善されても、液晶表示素子の助作原理から補 助光源としてのバックライトが不可久なことに变わりはない。高画䆩高品頁のカラ一液 晶ディスプレイが要求されることにともないバックライト用光源の性能改善だけでな、 バックライトの方式モのものや光源の点灯方式についても、さらなる改善や新しいアイデ アが期待される。

[差支献]

(1)两角伸治：液晶ディスプレイの将来動向, 信学技報 EID $90-7$ (1990)39-44

（2）小原章：液晶表示用バックライト，照学誌73-12(1989)784-770

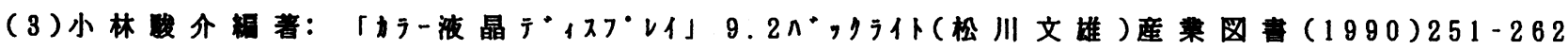

(4)友清克彦: フラットパネルディスプレイ・91, 日維 B P 社 (1990)207-210 